With the Compliments of Dr. CHARLES U. SHEPARD, Jr.

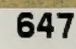

554

opy 1

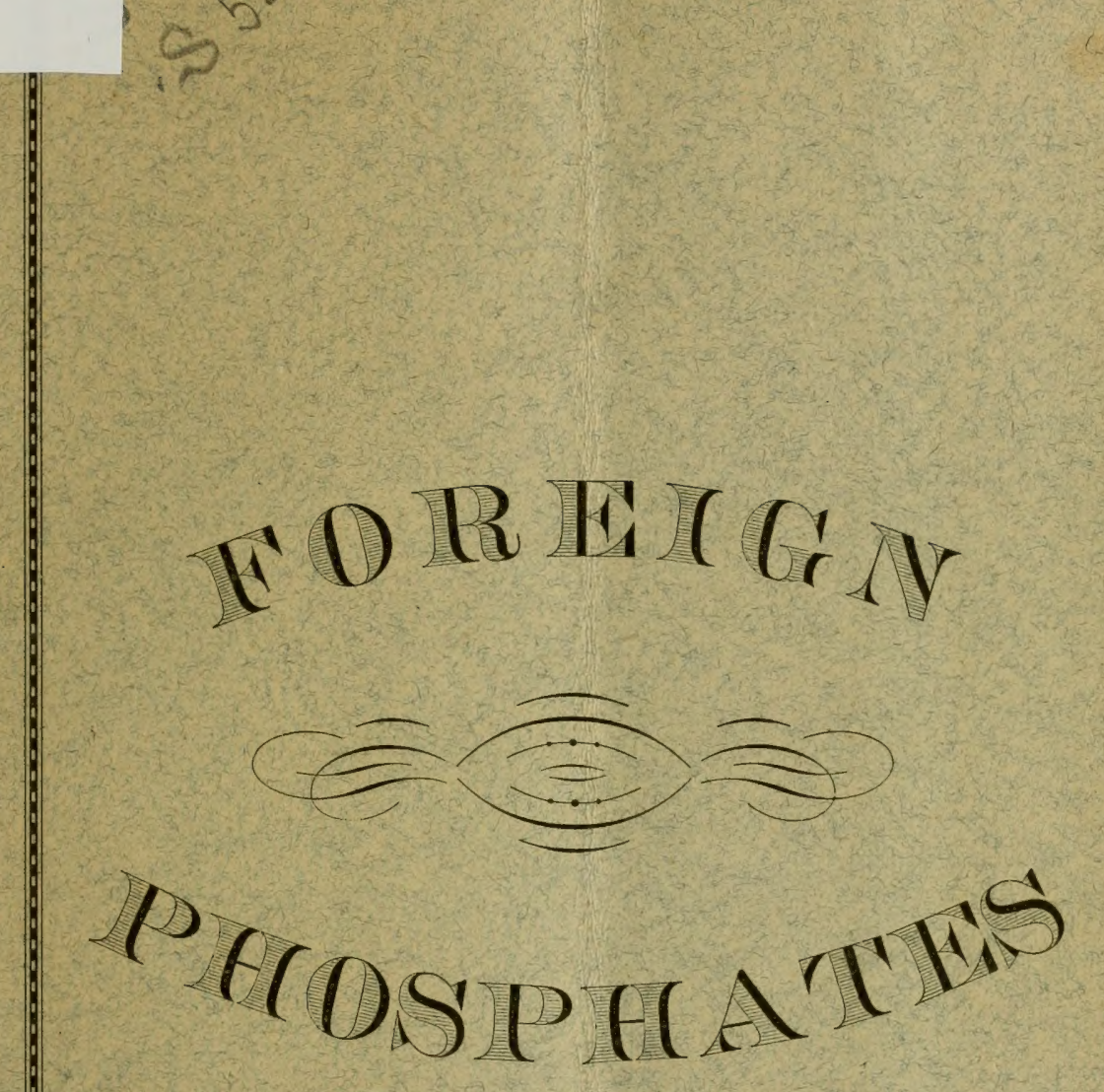





\section{FOREIGN PHOSPHATES,}

0

BEING

\section{A LECTURE}

DEIIVERED BEFORE

The Young Men's Christian Association, A PRIL 21, 1879 , By Dr. CHARLES U. ${ }_{i}$ HEPARD, Jr.,

CHARLESTON, S. C.

TIIE NEWS AND COURIER BOOK PRESSES: I879. 


\section{$\mathrm{NOTE}$.}

The journey to the various European deposits, which constitute so important a part of the beds described in this Lecture, was undertaken at the instigation and expense of Wm. L. Bradley, Esq., of Boston, Mass. 


\section{FOREIGN PHOSPHATES.}

Having been requested to deliver to you a lecture, and the choice of the subject being left to myself, I will invite your attention to a short consideration of the more important foreign phosphatic deposits.

At a time when the production of the various Carolina mines has reached two hundred thousand tons per annum, causing the disbursement of over one million dollars in this neighborhood, and thereby bringing a comfortable support to many thousand individuals, besides returning a large income to the State; when many men are considering the question whether they, too, will embark in the mining industry, and thus yet swell the yearly product, it is obviously a wise course to consider what are the sources, other than our own, to which the civilized world looks for its phosphatic supply, and how formidable they are or may become as competitors in its markets.

Without dwelling on the general principles which underlie the use of commercial manures, i. e. the depletion by successive cropping of certain indispensable elements of plant-food, and the well-established insufficiency of stable or farm manure to counteract this deficit, we will best consider what constitutes commercial phosphates, and to this end must review their history.

The history of commercial manures is essentially that of the practical recognition of phosphoric acid. The use of bone and ivory clippings from the knife and button factories of Sheffield, England, by the neighboring farmers, was most probably the first application of purely phosphatic manures. This material, amounting to eight hundred tons annually, was regarded as waste until the middle of the last century; the manufacturer's sole thought concerning it was 
to prevent its accumulation about his works. In I774, Hunter first publicly advised the agricultural use of bones. From so restricted a beginning, and so recently, dates the present vast consumption of phosphatic manures, which failed, however, to assume any great commercial or agricultural importance until after 1820 ; and-it is interesting to note-even then without a just appreciation of what, as we now know, constitutes the true value of bones.

It was only through the experiments of Justus von Liebig, based on the researches of de Saussure and others, that phosphate of lime was thus recognised. The Duke of Richmond's direct field experiments on the use of bones were instituted in 1843 . They were undertaken to demonstrate that the action of calcined or boiled bones (i. e. bones deprived in whole or part of their grease and gelatine,) is not inferior to that of crude and fresh bones. His conclusion, which controverted the prevailing opinion, was that the fertilizing principle of bones lies ncither in grease nor in gelatine, but rather in phosphate of lime, and more especially in phosphoric acid, and not in lime.

The agricultural application of, and consequent demand for bones outran the scientific investigations on their mode of action. A factory for grinding bones was established early in this century at Hull, in England. The bone-meal succeeded so well, especially in the cultivation of turnips, that the butchers soon became unable to supply the demand, and this also, in spite of the enormous consumption of meat in England. Resort was had to importations from the Continent, where the agricultural value of bones was less appreciated. The effect of this enormous use of bones was to restore the fertility of many exhausted counties. Land advanced greatly in value; and heavier crops brought wealth and comfort to all classes of the community. Bones were everywhere carefully collected and shipped to the great commercial centers, or locally applied to the fields, as seemed most profitable. Not only were they obtained from the slaughter-houses and refuse heaps of Europe, but they were imported in vast quantities, generally in the 
form of burnt bones (the so-called bone-ash), from South America. On the immense plains of La Plata and the Brazilian Rio Grande there grows a long and fine grass, which supports enormous herds of cattle and sheep. These were originally imported from Europe, but have now increased so rapidly as to number, in some districts, one thousand head to every inhabitant. The horns, hides and fat of these great droves of cattle are exported; the tongues are eaten; a small part of the meat is utilized in the manufacture of Liebig's extract, the rest is allowed to decay, or is consumed by hogs and wild animals. The bones are used for fuel (there are no trees in this region) in obtaining the fat, which causes an immense quantity of burnt bones to accumulate on each farm. In addition to these heaps about the slaughter-pens, there are in some places on the pampas, huge accumulations of bones, marking the spots where whole droves of cattle have succumbed to thrist, in times of drought, or have been consumed by a conflagration of the grass.

In 1872 , ninety-seven thousand seven hundred and seventy-eight tons of different sorts of bones, worth over three million dollars, were imported into Great Britain alone.

Meanwhile another equally active demand had sprung up for bones. The cultivation of the sugar-bect on the Continent had assumed great dimensions, and bones were eagerly sought after for conversion into bone-black and use in the clarification of sugar-beet syrups, or of crude sugars imported from the Colonies. Happily for the farmers, at the time when this competition was beginning to seriously affect the price of bones, a substitute was found. Coprolites, whose occurrence on both sides of the English Channel had been known since about I 820 , began to be employed in lieu of bones. About the same time, followed the introduction by Liebig of acid phosphates, manufactured from bones (I 840), and from coprolites by Lawes shortly after.

Immediately the interest in phosphatic materials of every 
kind was stimulated by the promulgation of their value and how best to utilize them. The deposits of apatite (mineral phosphate of lime), in Estremadura, Spain, had been known for many years, but their value was unappreciated until the visits of Daubeny and Widdrington in 1843 . Numerous deposits of phosphate of lime began to be discovered and extensively excavated in France, Germany, Norway, America, the West Indies and the Pacific Ocean.

\section{SUPER-PHOSPHATES.}

That we may arrive at the commercial value of the various phosphatic materials to which your attention will be directed later, it is desirable for us to inquire briefly how phosphatic enrichment of the soil is accomplished. The generally adopted form for applying bones and mineral phosphates to soils is the so-called super or acid phosphate. This is the product of the treatment of the finely pulverized material with sulphuric acid. The phosphoric acid contained in bones and mineral phosphates occurs combined, i. e. chemically united, with various so-called bases, as lime, magnesia, oxide of iron or alumina, in compounds that are practically insoluble in water. The effect of treating the above mentioned phosphates with sulphuric acid is to render the phosphoric acid, therein contained, more or less completely soluble in water. Now, the first application of sulphuric acid to phosphates was in consequence of the then prevailing opinion that plant-food must occur dissolved in the water found in soils, and in order to effect the appropriation of phosphoric acid by plants it was (and by some, yet is) held that phosphoric acid must be applied to the soil in a condition soluble in water.

But it is well known that the soluble condition of the phosphoric acid in super-phosphates ceases on their intermixture with moist arable soils. It is arrested in the soil; held there for use by vegetation, in new combinations that are insoluble in water. Why, then, the necessity of bringing about, at great expense, a soluble condition of the 
phosphates, if on their application to the soil they are to revert to their former insoluble state?

We hold that the ends accomplished in the treatment of ground phosphates with sulphuric acid are their finest subdivision and most thorough intermixture with the cultivated earth, which conditions best ensure their spedy assim $x^{2}$ ation by plants. The finest mechanical pulverization of bones or mineral phosphates yields a powder whose grains, if invisible to the naked eye, are easily discernable under a magnifying glass. But the chemical transformations (to which we have just referred) of the same material afford a product whose particles are so minute that they become almost invisible under the strongest microscope, and susceptible of solution, if not in ordinary water at least in the waters of the soil. The finer the particles and the more porous the structure, the larger is the surface exposed, and the more efficacious the action of any solvent.

The treatment with super-phosphates also accomplishes a more rapid and complete incorporation with the soil of phosphoric acid than can be obtained in any other practicable way, because the fixation of the soluble acid, dissolved in rain or other water, takes place under ordinary circumstances, more or less gradually, and is probably not confined to the point of its first contact with the soil, but reaches through a certain extent of earth, into whose finest interstices the phosphoric acid finds its way, to be thus commingled (on its retention) with every particle.

Whether, then, it is held that the function of the superphosphate is to furnish to the plant directly soluble pabulum, or that it effects the most favorable subdivision and distribution in the soil of this indispensable ingredient of plant-food, you perceive that the greater the amount of soluble phosphoric acid in a super-phosphate, the better adapted it is for accomplishing its purpose. In estimating, therefore, the value of any phosphate, we may inquire, as our basis of comparison, with how large a content of soluble phosphoric acid can a merchantable super-phosphate be prepared from it? 
I am not unmindful that this criterion will meet with objections, and, did time allow, would gladly discuss the many questions involved. But those who are unwilling to accept it, must at least concede that almost the entire phosphatic production of the world is converted into superphosphates, whose commercial, if not their agricultural, valuation is based on their content of soluble phosphoric acid.

Our aim being, therefore, to produce phosphates which shall yield the highest grade of solubility in the manufactured article, it is wise to put each material to the actual test, and to inquire carefully as to what constitutes a favorable crude phosphate. Obviously the more phosphoric acid in the natural material the better. We find it combined with lime and magnesia, and those compounds are favorable for the preparation of acid phosphates. But phosphoric acid occurs united sometimes in part, (in company with the phosphates of lime and magnesia,) sometimes almost wholly with oxide of iron and alumina-and these modes of combination interfere materially with the preparation of a merchantable superphosphate, i.e. such as may be bagged and applied in a drill; nor in fact do they permit of a high grade of solubility in the manufactured article. Then we find larger or smaller quantities of carbonate of lime and fluoride, or chloride of calcium-which, if present to the extent of only a few per cent., prove of assistance in attaining a dry product, but if more abundant, cause a wasteful use of acid and deleterious fumes. Finally, there are always present greater or less quantities of substances that may be regarded as diluents, chief among which may be mentioned sand.

Thus, the more phosphates of lime and magnesia that are contained in a phosphate, the better, ceteris paribus, shall we find it answering to our value-test. Exceptions do occur to this rule, and some instances will be brought to your attention later on.

For the sake of convenience we will consider the various commercial phosphates in the following order: 
GUANO,

$\triangle$ LTERED GUANO,

FOSSIL BONES,

COPROLITES,

Phosphatic materials whose near origin is clearly animal.

PHOSPHORITE, , Phosphatic materials whose near origin is mineral.
APATITE,

GUANO.

It is well for us to include guano in the above list, not only because of its very considerable phosphatic content, (say twenty to thirty per cent. of phosphates,) but also because of the serious competition which it must exert in the agricultural world so long as its supply holds out.

I have referred to the important influence of bones in the introduction of phosphatic fertilizers; but there can be no doubt that the enormous consumption of Peruvian guanothe result of its well established agricultural value-and its subsequent advance in price, as also its late deterioration in quality, paved the way directly for the present vast trade in manufactured manures. The extent of the trade in guano may be realized from the statement that Great Britain alone imported of this article in the period 1844 to to 1873 , five million two hundred and fifty thousand tons, valued at over three hundred million dollars.

With regard to the quantity of guano still remaining at the disposal of the Peruvian Government (and almost all real guano is, or rather was, Peruvian,) the statements are most contradictory. On the one hand, we have the assertion of that Government that they possess some forty to forty-five localities, containing more or less extensive deposits of merchantable guano. On the other hand, the British Consul at Callao, reported, in 1873 , that Peru did not possess three million tons of exportable guano. This would last at the present rate of shipment only a year or so longer. The complete exhaustion of the Chincha guanothe best of the Peruvian-and the probably early consumption of the Guanape-judging from the fact that cargoes of inferior guanos are being exported from yet other Peruvian 
localities-lead the public which has invested in Peruvian bonds, secured on the guano-returns of the Government, and those who depend on this article for agricultural purposes, to infer that the enormous excavation of these beds has, at last, almost exhausted what at first sight appeared to be a boundless supply. Such at least is the belief among the English holders of leruvian bonds, and the manufacturers of commercial manures at home and abroad. Even the most hopeful look forward to the complete exhaustion of the Peruvian, and all similar beds, before the end of this century. At the present time, it is doubtful if the annual importations of nitrogenous guano into Europe and the United States cxcceds one hundred to one hundred and fifty thousand tons - a mere bagatelle when we remember that it has almost reached six hundred thousand tons for one year.

The decline in quantity and quality of unaltered (especially l'eruvian) guano, steadily augments the demand for those manufactured manures which are designed to supply its place. These are the so-called "complete manures;" completc because in addition to phosphoric acid, they contain nitrogenous matter, potash and other more common bases, cach and all important as elements of plant-food and occurring in the old favorite guano.

For our present purpose, it is unnecessary to say more conceming suano beds, than that they are due to the acexe mulation of countless multitudes of marine birds, with which are mingled their feathers and their bodies, when dead, and, also, the carcasses and dung of certain sea animals, such as the sca-lion, seal and walrus. Certain natural conditions are necessary for the accumulation and preservation of guano, these are: I. Extreme abundance of fish food. 2. Total absence of rain. 3. Limited area of the islands or promontories serving as resting and brooding spots. 4. Solidity of the rocks of these latter.

Unaltered guano constitutes a more or less fincly pulverulent mass, of a light yellow color and a strong ammoniacal odor, with white, ycllow or brown lumps interspersed through it. 


\section{ALTERED GUANOS.}

A-Those retaining thcir pulverulcut form.

The changes which guaro deposits undergo are due to physical and chemical causes. The chicf physical causes are lixiviation by water (rain and occan) and volatilization from solar heat; the chemical are decomposition under the influence of water and heat, and contact with the constituents of salt-water and the rocks or soil on which the deposit has been formed. It is convenient to divide the altered guanos into (A) those that have to the greater part preserved their original pulverulent form, and (B) those that have been transformed into rock formations.

It may be observed that a sharp distinction is impossible in this division, since deposits occur where all the stages from fresh guano to rock-guano may be obscrved at various depths in one and the same locality; and, thercfore, the order accorded to the various deposits must be governed largely by convenience.

The Mcxilloncs guano occurs on a promontory about twclve miles wide and forty long, which stretches out into the South Pacific Ocean at the point where the States of Bolivia and Chili meet. The harbor on the North is cxcellent. But the region is inhospitable and uninhabitable; there are violent winds, no rain, no potable water, mists until ten o'clock every morring, and then cxtreme heat from a cloudless sky; a sandy or rocky soil, and no vegetation. The coast steamers have here a coaling station, whose inhabitants arc obliged to bring their food from a distance, and trust to distillation for their water. The rocky promontory before alluded to is from one thousand to twentyfive hundred feet high, and is covered generally with sand. The guano deposit occurs on its slopes, the chicf mass being found at an elevation of seventeen hundred feet above the sea; in places its thickness is forty fect. Altogether there are supposed to be several million tons. The deposit is difficult of access, and the guano has to be brought in sacks 
by a mountain path, one mile long, to an inclined way down which it is cast to the mole below. The capacity of the works is two hundred tons per diem.

There is a light covering of sand and stone, which has to be removed. The deposit has a remarkably uniform composition: the lower strata, however, contain less moisture and more nitrogen, and are, consequently, more valuable. The guano is light-yellow in color: consists of threc-fourths powder and one-fourth lumps. The lumps are readily pulverized; the powder is light in weight and easily suspended in water. It is a lixiviated bird-guano, from the action of saltwater, and contains a larger a mount of phosphoric acio in proportion to the content of bases than we find either in bones or most other phosphatic materials; and consequently we are not surprised at its comparatively greater solubility in weak solvents. Manufacturers have expcrienced great trouble in their attempts to make from it a dry, high-grade superphosphate.

The shipment of Mexillones guano is mostly to Germany, whither as much as twenty thousand tons have been brought in one year. It is claimed that England consumes several thousand tons annually.

The tendency of the super-phosphates made from the Mexillones article to remain in a soft and pasty condition, and the consequent difficulty encountered in the attempt to prepare a dry and merchantable product from it, must interfere with the ready consumption which its apparent richness in phosphoric acid would seem to promise. But whether this obstacle can be overcome or not, the very recent outbreak of hostilities between Peru, Chili and Bolivia must certainly impede, if not arrest the exportation.

\section{THE PACIFIC PHOSPHATES.}

The United States Congress, in 1856 , put under the protection of the Union all the guano islands lying in the Pacific Occan, for ten degrees North and South of the Equator, and between one hundred and fifty and one hundred and eighty degrees West longitude. 
All of these islands are small and low, formed of coral recfs on submerged volcanic peaks; they generally contain a lagoon of salt-ivater, and are surrounded by coral reefs. The lagoon becomes gradually filled with coral fragments and sand, and then covered with guano, since the islands constitute the only place of refuge and breeding for seabirds in a vast expanse of ocean. Most of the islands are liable to rain storms, which wash out, and sometimes off, the facal accumulation, and support a scanty vegetation of bushes and low trees. The annual fall of rain is not great, but under the influence of the equatorial sun, it produces a rapid decomposition, whose products are wafted away by the steady trade wind, or, dissolved in water, sink into the mass. Characteristic for these deposits are the absence of nitrogenous matter and the high percentage of phosphates, with fine pulverulent condition. Underneath this fine massin which hard crusts and lumps may occur-is sometimes found a very rich phosphatic rock, the result of the infiltration of a solution of the phosphatic salts from above, into the coral rock beneath.

The analyses of a number of specimens of such rock guanos from Enderberry Island gave an average of 39.08 per cent. phosphoric acid.

Of late years the shipments from these islands have fallen off from many thousand tons per annum to but a few thousand ; the bulk of the cargoes going to Germany, where they bring a high price (thirty to forty dollars per ton,) by reason of their adaptability to the manufacture of the high grade super-phosphates employed in that country-which are sold to contain twenty per cent. soluble phosphoric acid. The voyage is long, and the difficulties and dangers arising from the want of any harbors at these islands, combined with the almost exhausted condition of the deposits, render their present working unprofitable.

$$
\text { B-Rock-guanos. }
$$

Under rock-guanos we understand those rock formations 
consisting essentially of phosphate of lime (or in a few instances of phosphates of magnesia, alumina and the oxide of iron,) which are derived from original deposits of guanos, and owe their present form to various physical and chemical causes.

Since the application of Liebig's method (of rendering bones soluble by the addition of sulphuric acid) to mincral phosphates, the rock-guanos have been much sought after on account of their generally high percentage of phosphoric acid, and the excellence of the super-phosphates manufactured from them. In consequence of this demand the IVest India Islands and other localities where such deposits are likely to be found, have becn carefully and repeatedly scarched. New beds of phosphatic guanos have been discovered from time to time, but owing to the smail quantities of available material that they usually contained, they have gencrally been soon exhausted, and thus have ceased to influence the market. Notable exceptions, however, have been the Monks', Sombrero and Curacoa rock-guanos, whose quantity and quality have entitled them to play a prominent part in agriculture.

At this day we scldom hear of any fresh and important discovery in the West Indies; and while it is not impossible that virgin deposits may yet be found and worked, such nevertheless becomes yearly more improbable, as prospecting partics have hunted through all the many islands, recfs and coasts of these unquestionably ancient guano regions. Whole islands have been, as it were, transported in ships across the scas, and the amount of phosphatic guanos annually thrown on the European market was enormous so long as the deposits held out. With the exception of the New Curacoa there is at present no large phosphatic deposits in the West Indies whose quality will permit of its slipment across the occan. Beds of phosphates containing, however, large quantities of oxide of iron and alumina (as the Navassa), or composed almost entircly of these objectionable ingredients (as the Redonda or Elroque), do exist in very extensive deposits; but the former meet with a very limited demand, 
and with the latter manufacturers refuse to have anything to do. With regard to the Monks', Old Curacoa and Sombrero Islands deposits, it is for our purpose only necessary to note their practical exhaustion long since; and of the New Curocoa we know little beyond the very promising reports that have been spread abroad concerning it. If this last mentioned source fulfills now only in part the expectations of its owner it must prove a very troublesome competitor for Carolina phosphate in the English market, since both its quantity and quality have been greatly praised.

Raza Island in the Gulf of California, has furnished a remarkably rich phosphatic rock-guano. The deposit was small and has been sent wholly to Hamburg. It has been in all probability ere this exhausted.

\section{FOSSIL BONES AND COPROLITES.}

Without dwelling on fossil bones, since separate deposits of this character are rare and small, we will pass at once to coprolites.

The truc coprolites are gencrally two to four inches long, one to two inches in diameter, gray to black in color, and have the shape of kidneys. Intcrnally they exhibit an carthy, dense structure like hardened clay, with a conchoidal and brilliant fracture. "They often contain the scales, teeth and bones of fish, which represent the undigested portions of food voided in the excrement; and they are occasionally found in such connection with the skeletons of fossil saurians as to show their original position in the intestincs." The investigation of these rounded fossil excrements proves that they were once finely ground, and when in a soft state were twisted spirally from center to periphery, and that then they received (in the intestines of animals) the ridges and corrugations that mark their surface. They occur largely in many of the secondary and tertiary formations, but especially in the Lias, in England.

The pscudo coprolites are phosphatic nodules or pebbles of gray or grayish-black color, of irregular ovoid form, and 
of the size of the true coprolites, with which they were at first confounded. They are undoubtedly of remote animal origin, and were probably formed in the following manner: Accumulations of decomposed animal detritus aeand exuvi were acted upon by carbonic acid water, which dissolved out the phosphates and transported them into calcareous earth, where they were precipitated and fixed by carbonate of lime. This process continued until the carbonate of lime was transformed into a rich phosphate of lime. The mass, originally soft and loose, hardened gradually, but under the wear and roll of water it was broken up and rounded into the phosphatic pebbles now found thrown upon the coast of Suffolk and other places. With them occur fragments of bones, teeth and often true coprolites.

There are three kinds of coprolites raised and sold in England :

I. The Cambridgeshire coprolites, occurring in the greensand over the gault, in color grayish-black, or more frequently grayish-green; they belong generally to the class of pseudo-coprolites, and are mixed with considerable calcarcous matter, sponges, coral, \&c.

The land about Cambridge and as far West as Shillington has been so thoroughly worked for coprolites that it may be safely said that little remains at an accessible depth of this once important deposit.

The yield per acre rarcly exceeds four hundred tons, and often falls to only one hundred and fifty. The cost of mining is enhanced by the great depth at which the remaining deposits occur; viz: ten to thirty fect, averaging fully twenty; as also by the high cost of the lands containing coprolites, say one thousand dollars an acre, or the equally expensive privilege to excavate the phosphates with the super-imposed obligation to afterwards restore the land to its proper level and replace the top-soil. The phosphatic seam is mined in an open trench, the top-soil being carefully removed and heaped up by itsclf, and the other superincumbent strata thrown over the excavated land. The 
entire seam is carried in horse carts to the washers, and yields about fifteen to twenty per cent. clean coprolites. The washcrs are simple circular tubs placed horizontally in the earth, in which the rock is kept in motion by large rakes propelled by steam-power, under a continuous stream of water. The capacity of each washer is about five tons per dicm. At the present prices for coprolites, there is little, if any, profit in their excavation.

2. The Suffolk or crag coprolites are hard and difficult to grind; they have a smooth, shiny surface and fracture, and a dark-brown color. They occur between the crag and the London clay in a seam three to eighteen inches thick, with a great variety and number of fossil bones and teeth; ordinarily at such depths as to hardly pay for their excavation. The Suffolk coprolites are generally somewhat inferior to those from Cambridgeshire.

3. Bcdfordshire coprolites; they are from the older green-sand formation under the gault, and contain much less phosphoric acid and more oxide of iron and sand, but are more abundant and accessible than those previously mentioned. They are dark in color, and contain from forty to fifty per cent. bone phosphate of lime.

The total annual yield of the various English coprolitic deposits is about twenty-five thousand tons. According to Prof. Albert Hunt's mineral statistics, thirty-five thousand tons of all grades were raised in 1872 ; their value being fifty thousand pounds, or about seven dollars per ton. While the difficulty of excavating these deposits has been increased by the previous exhaustion of the more accessible beds and the higher cost of labor, forcign phosphates have been introduced in great quantity, and of much supcrior quality, so that the English coprolites have long since lost the importance which they acquired soon after their first utilization.

\section{French Coprolites.}

Of coprolites (using the term in its commercial significa- 
tion) there are three important deposits in France, viz: the Bologne or Calais, the Ardennes and the Bellegarde.

Phosphatic nodules have been found on the Northeastern coast of France, from Havre to the Flemish border. They are very similar to the inferior quality of Bedfordshire coprolites; are hard to pulverize, of grayish or greenish-black color, but generally larger than the English. They contain a large amount of sand and frequently of oxide of iron and alumina, so that they can be employed only in the mantacture of low-grade articles. Nevertheless they are extensively imported into England.

The so-called Ardcnnes phosphates possess greater importance, as they are largely and successfully used in French agriculture, in the simple, finely ground powder. The nodules are from onc-half to three inches in diameter; in color, externally, gray or greenish-brown, internally of a bronze tint. With them occur abundantly phosphatized shells, petrified wood, fossil tecth and bones. The deposit comes to the surface in places, but the economic excavation takes place ordinarily by open trenches. The actual cost of the ground phosphate is about ten dollars per ton, which leaves a very small margin for profit, as it is principally sold in Brittany at fourteen dollars. The annual production of these beds was estimated in I 872 at twenty-five thousand tons, and has increased since then very materially.

The Bellegarde phosphates consist largely of phosphatized shells, occurring in an argillaceous sand belonging to the gault. They are worked both by open trenches and galleries, the rock which is richer in phosphates being removed to the open air, where it is piled up and allowed to weather before being ground and further treated. An examination of the principal mines failed to corroborate the extraordinary statements that have been published in regard to the cxtent and quality of this deposit. The Bellegarde phos. phates may possibly exercise considerable local influence, but the low content of phosphoric acid in the material found on the spot would prevent its wide shipment. This deposit occurs where the Rifne enters the French territory. 


\section{PHOSPHATES OF MINERAL ORIGIN.}

There are very important beds of phosphate of lime, (more or less pure,) whose origin cannot be traced to animal life, but is rather referable to mineral sources. Whether the phosphoric acid contained in them belongs to the primeval mineral stock of that ingredient, or at some exceedingly remote period was a constituent of animal bodies and, after complete chemical disintegration, has arrived at its present condition, must be left to the future for decision. The question lacks practical importance.

The material from these phosphatic deposits may be divided into crystalline (or sub-crystalline) and amorphous (not crystalline). The terms usually applied to these mineralogical varieties, are "apatite" for the former, and "phosphorite" for the latter. One of the distinctive characteristics of apatite is its greater hardness.

\section{PHOSPHORITE.}

The Russian phosphorite (locally known as the "Samorod") occurs generally in the strata of the cretaceous formation, it is also, however, found in those of the Jurassic, Tertiary, and even the Silurian. In the cretaceous, the phosphate appears more frequently as a deposit underlying the white chalk, sometimes it is discovered under the green sand. Elsewhere the deposit crops out on the surface of the earth, being disseminated in nodules through the cultivated soil. The area of this bed between the Dnieper and Volga Rivers is estimated at about fifty million acres, and there are yet others already discovered of greater or less abundance.

M. Yermoloff, who assisted Prof. Engelhardt in the recent gcological and economic survey of Russia, has stated: "Wc do not think that we exaggerate when we say that Central Russia reposes on phosphate of lime, with which she is able to pave the half of Europe."

In the beds of the central belt, between Smolensk, Orel, 
Koursk and Veroneje, this phosphate occurs either as separate nodules or in large flat masses, (similar, indeed, to the forms of Carolina phosphate,) of a grayish or brownish color, in a seam capable of yielding certainly over one thousand tons to the acre, if not so much as is claimed by Yermoloff, viz: six thousand tons per acre.

One of the best localities for the inspection of the "Samorod" is at the village of Jablovky, in the district of Dmitrofsk, Government of Orel. There the rock comes to the light on the sides of gullies, water worn in the rolling country. Its depth from the surface varies from two to ten feet, and more. The stratum underlies undoubtedly an immense extent of country, but apparently at such depths that even if its quality were good, it would not prove remunerative to carry the excavation beyond the ravines where it has been exposed by the water courses. The "Samorod" forms there, more or less flat irregular blocks, one or two feet square, and eight to twelve inches in thickness. Their upper surface is smooth, shiny and mammillated; the lower, which is irregular and uneven, shows plainly that they are composed of nodules held together by a siliceous and calcareous cement. The nodules are hard, of a dark gray color; they emit a naphthous odor on friction, and contain a great deal of sand, whose particles are plainly visible to the naked eye. The "Samorod" is apparently the only rock occurring in this region, and, consequently, scrves as a stone for the construction of foundations and chimneys, as also for macadamizing high ways and ballasting railroads. An examination into the commercial value of these deposits, led to the conclusion that where the phosphate rock is accessible, its quality is too poor to admit of its more than local utilization; whilst the richer nodules occurring, as they do, disseminated through a compact formation, cannot be mined profitably. Only one local attempt had been made to agriculturally utilize these vast deposits, and that had proved a failure.

The Wclsh and Bohcmian black phospluatic shales are comparatively unimportant deposits, as their generally low con- 
tent of phosphoric acid and large percentage of oxide of iron preclude their use in the manufacture of super-phosphates.

The Bordcaur phosphates-as the phosphorite obtained from the Departments of Lot, Tarn-et-Garonne and Aveyron is commercially called-on the other hand, have played an important part in the English markets. The principal mines in 1875 were behind Cajarc, and not far from Larnagol, situated on the top of some high hills, several hundred feet above the level of the river Lot, which flows at their base. Phosphate crops out on the surface at several places, and was formerly collected from the fields, and used in the construction of stone walls. The formation of the region is a Jurassic limestone. The phosphatic rock occurs in pockets and fissures in the limestone, accompanied by a red phosphatic clay, and, occasionally, in other localities, by the fossil bones of the rhinoceros, mouse, bat, birds, land turtles, and other animals. The phosphate is white or colored, sometimes of a red or dark brown color; massive, or in thin lamellax, (often compactly united,) or again in nodules frequently with a differently colored kernel of rock or, sometimes, of clay.

The pockets of phosphate are extremely irregular, so that the yield and even the quality of the beds are very uncertair. "The Pearl" mine at Mas-Merlin afforded several thousand tons in a short time. In 1875 it could hardly pay: but it was bcing worked in the hope of striking a larger mass. On either side of it were mines, then abandoned, which had yielded small quantities. The phosphate seems to have filled an irregular fissure at "The Pearl" mine, being enclosed by the dolomitic limestone, with here and there a mass of the red clay before mentioned. It came to the surfacc, and appears to have attained its greatest thickness within a few yards of the top; at the depth of seventy-five feet the phosphate rock became very thin and uncertain. The mass was, in places, ten feet thick, but ordinarily, it consisted of several more or less parallel and thin bands, often ending abruptly. The cxcavations for the 
phosphate were from twenty to thirty feet broad, about fifty to seventy-five feet deep, and from one hundred to four hundred feet long. Most of the beds were practically exhaustcd. Some of the best phosphate was excavated in sufficiently clean picces so as to require no washing, and sold in the English market for thirteen to fourteen pence per unit of bone phosphate of lime when varying from sixty to seventy per cent., and from fourteen to fifteen pence per unit when above seventy per cent. The remainder of the rock was passed through a simple horizontal washer driven by steam, and, being of a low grade, is consumed in the French market.

The lumps of the first quality (the "piece-rock") were usually several inches in diameter, and of a bright color, while those of the second quality were about the size of hazcl nuts, and of a reddish color, containing considerable oxide of iron and alumina.

No new deposits have been discovered in these regions during the past six years notwithstanding ccntinued and careful prospecting; and the general impression prevails that the better part, both in quality and quantity, has already been sent to market. The production has reached twenty thousand tons per annum.

In addition to the varieties before mentioned, there occurs many very beautiful specimens of bright color, brilliant lustre and fantastic form, often covered with delicate manganitic dendrites. The origin of the deposit is concretionary. The phosphate is supposed to have been deposited out of solution by warm saline springs.

The Gcrman plosplaatc, which occurs along the Lahn, is attributed to the concentration in limited beds and pockets of the small content of phosphate of lime found in the limestone of that region. Without entering upon a detailed description of the Lahn phosphate, I will confine mysclf to a brief description of the most important mines in this deposit, viz: those at Dehrn, between Limburg and Weilbach.

The mines are situated upon some high hills on both banks of the Lahn. The land belongs to private individuals 
and the several towns in the vicinity; it is generally worked on a royalty. The phosphorite occurs almost entirely in pockets in the limestone, without any special indications on the surface. This necessitates boring to ascertain the existence of the deposits, and the country abounds in abandoned experimental shafts. The pockets are found at various depths (eighty to two hundred feet) from the surface. Descending the shafts by the rude bucket and hand-windlass, here ordinarily employed, I found the phosphorite to occur in a very irregular bed, with a thickness of a few feet at best. Galleries are worked to the ends of the pocket. In places the rock does not require blasting, but dynanite is generally used in the shafts and galleries. The excavated phosphate is assorted into "piece" and "wash" rock. The former consists of large pieces of more or less pure phosphorite, which are cleaned by hand and hammer from adhering impurities. The latter consists of small fragments or masses covered with clay, \&c., which are transported to the steam washers on the river, and then cleansed as much as possible. When ready for the market, the "wash" rock is about hazel-nut size, or even smaller, and generally of a decidedly reddish color. It contains very considerable quantities of oxide of iron and alumina. The "piece" rock constitutes only about one-fifth of the product of the mincs, and is often much vitiated by the oxides of iron and manganese, and alumina. The pieces rarely exceed the size of a man's fist. The region, where the pockets were being worked, embraced but a few hundred acres; and considerirg the difficulties and great cost, as also the adverse feeling of manufacturers towards the rock, it cannot be expected that these deposits will realize the hopes entertained when they were first discovered and mined. The production at Dehrn had been very considerable. One proprietor had raised fifteen thousand to twenty thousand tons per annum, but in 1875 he was producing about four thousand tons. A very considerable quantity of clean rock was being held for better times and prices, which, I fear, will never come for it, considering the objections to the 
Lahn phosphate. These do not refer to a low content of phosphoric acid-for it is possible to secure consignments guaranteed with phosphoric acid equivalent to seventy per cent. bone phosphate of lime-but rather to the presence of large amounts of oxide of iron and alumina, which prevent the production of high-grade and dry super-phosphates. The best average price paid for Lahn phosphate, on the spot, rarely exceeds eight dollars per ton. The better qualities are shipped to England for the manufacture of super-phosphates; the medium qualities are similarly used in England; and the poorest sorts are reduced to powder for direct application to the soil.

\section{Spanish Plospluoritc.}

The existence of beds of phosphate of lime in Spain has been long known, although it is only since a comparatively recent date that their true composition and value have becn appreciated, and yet later that active mining opcrations have been carried on at the different localities. The mineral has long borne the name of "fosforita" from the phosphorescent light produced by throwing its powder upon live coals in a dark room. In former days it has been employed as a stonc of construction. Logrosan and Cáceres are the two principal localities for phosphates in Spain; they are situated in the Province of Estremadura.

Logrosan is a wretched mountain town of some ninc hundred souls; is distant nearly thirty miles from both Trujillo and Villanueva de la Screna-the latter being a station on the railway from Madrid to Lisbon. There are several distinct veins of phosphorite at Logrosan. I will confine myself, however, to the description of the principal one, called "Costanaza," as also "Nuestra Señora del Consuclo," at the time of a visit to it in 1875 .

The mine was idle. Operations had becn suspended in conscquence of legal injunctions, and the officers of the company had been forbidden to dispatch the (possibly) ten thousand tons of phosphorite that lay piled up beside the 
mine. Some six hundred men had been previously employed about this mine.

The vein has been so well developed that the immense quantity of the deposit is readily apparent. Its total length is about two and a half miles; the river starting from the foot of Mt. Boyales, at the North, and traversing the intermediate plain for the distance of almost one mile, cuts and crosses the hill on which stands the chapel Nuestra Señora del Consuelo, and continuing its course in a Southeasterly direction, extends for the distance of a mile to a hill covered with cork-trees. The mining operations have been chiefly carried on where the phosphatic vein crosses the elevation near the chapel, but pits have been opened along its entire course, which is easily followed by its appearance on the surface.

The general formation at Logrosan is a silurian argillaceous schist (slate), through which conical masses of granite have forced their way, as also the almost perpendicular metamorphic veins of phosphorite. Accompanying the phosphate, and often running through it, are bands of coarse quartz. The walls of slate enclosing the vertical phosphatic vein exhibit considerable decomposition and disintegration. The width or thickness of the vein of phosphorite averages ten feet, although in places it swells out to twenty feet and more, and is then apt to contain parallel streaks of quartz and the gangue or enclosing rock. At the center of the excavation, viz: on top of the hill, and near the surface, the vein is unquestionably thicker than at the ends and bottom of the trench, although the phosphorite extends both longitudinally and vertically.

The purest phosphate and greatest yield was obtained at the depth of a few feet from the surface. The depth to which the excavation had been carried varied from ten to forty feet; the length of the trench was about half a mile, it seemed quite free from spring-water. The rock is blasted; the larger pieces are cleaned by hand and hammer, and then assorted into high and low grades. The pieces of trimmed rock average three to four inches in diameter. 
The presence of the scams of quartz constitutes a much greater annoyance than the generally outlying clayey slate. Carbonate of lime does not occur, apparently, at this locality.

The Logrosan phosphate has a sub-crystalline structure; it does not produce electricity, and is inodorous, even on friction. Its texture is somerwhat fibrous, some pieces exhibiting a brilliant, radiated structure, resembling a feather. Although the large masses are readily broken and crushed, the fine pulverization of this phosphorite is difficult. To the touch it is soft, its streak is ferruginous and chalky. Its distinctive characteristic is the green phosphorescent light it imparts to fire. The friction of two pieces on each other creates phosphoresence. The highest grade rock is rosywhite or yellowish-white in color, soft, of a concentric structure, often radiated, with a mammillary or conchoidal surface. Reddish spots (from iron) and beautiful dendrites (from manganese) are not infrequent. The poorer qualities are milky-white, vitreous, hard, and contain considerable silica.

The shipment of this phosphate necessitates great trouble and expense. It is transported in heavy wagons, drawn by mules or oxen, and carrying two to two and a half tons to the load, to the railway at Villanueva de la Serena. The carts make two trips a week, and receive about twenty cents per hundred weight. The cost of transportation and handling until the phosphate is put on shipboard at Lisbon, amounts to almost ten dollars a ton, and the expenses reach fifteen dollars by the time the rock has been landed in England. It is claimed that it brings twenty-five dollars per ton in the English market. A railway to Villanueva would reduce the freight expenses materially, but would itself cost one million two hundred thousand dollars. This line, once constructed, would permit of the delivery of simply enormous quantities of this high-grade rock to the cxclusion of a corresponding amount of the Carolina and other rocks of lower value. The officers at the mine stated their readiness to suarantee their product at seventy-five to eighty-five per cent. bone phosphate of litne, as also their 
ability to. raise and lay down their phosphate beside the mine at less than three dollars per ton.

I have dwelt at such length on this mine, because it is apparently the only great competitor in the future which threatens seriously our local industry. Of the quantity and quality of the Logrosan phosphate, there can be no doubt; happily, however, such is the tardiness of Spanish Courts, it may be long locked to commerce; and, even then, so great is the disinclination of the capitalists to investments in the interior of Spain, it may be equally long before rail connection with the coast is made.

The Cuccres Mincs, on the other hand, are our present competitors in the English market, and, as such, descrve special notice.

Cáceres lies forty-three miles to the North of Merida, a station on the railroad from Madrid to Lisbon, and not far from the Portuguese frontier. The road to Cáceres is macadamized, but owing to its constant use by some four hundred ox and mule carts, burdened with phosphorite, its condition is wretched. The carts are similar to those employed at Logrosan, and the rate for the transportation of the phosphate to the railway about the same, although the distance is greater, because there is no pretence of a road from Logrosan.

The principal mines at Cáceres are united in the "Fraternidad" Company, and bear the names of the Esmeralda, Estrclla, San Eugenio, San Salvador, Perla and Lucero. The superficial extent of each of these properties is about thirty acres, with the right of future extension, if requisite.

From I866, when mining operations began, to October, i 875 , this company had furnished about one hundred and twenty-five thousand tons. They received from two dollars to three dollars and fifty cents, according to the quality, for the rock at the mines. The cost of transportation to Lisbon amounts to about eight dollars per ton. The chemical analysis of the rock gives from fifty-three to eighty-six per cent. of bone phosphate of lime, with an average of about sixty to sixty-five per cent. 
The formation at Cáceres is different from that at Logrosan, in that viens of dark limestone accompany the phosphorite and quartz which have burst up through the clayey slate. The "Esmeralda" mine-which is the largest and best-has two distinct veins, shooting up from below at an angle of about forty-five degrees, and penetrating the side of a hill some three miles from Cáceres. -The thickness of each of the veins varies from ten to thirty feet, with a variable quantity of enclosed gangue. They have been excavated to the depth of about one hundred feet, and show only slight irregularities in their course. Although the vein appears to become narrower as it is followed into the hill, the floor of the mine and the ends of the galleries consist of high-grade phosphorite. This is enclosed by walls of hard, brown limestone, towards which it is itself white and compact, but at the centre of the vein it is softer, crumbling easily, and has a rosy color.

In this mine less of the hard, vitreous rock is found than in the others.

Without entering upon a description of the other mines of this company, some of which were closed, I will only add that the total recent production has been about twenty-five thousand tons annually; and that the rock is of two kinds; the one, granular and of a light-yellowish or pinkish color, crumbling easily; the other, vitreous and hard, white in color, with occasional streaks of quartz or limestone.

Most of the Spanish phosphate gives to England, whither thirty-three thousand tons were shipped in I874. France also consumes a few thousand tons. The Spaniards make no home use of their rock, although their lands stand in sore need of such enrichment.

The Spanish phosphates are very difficult to grind, but nevertheless make good super-phosphates, which dry readily, and do not lose in soluble phosphoric acid, as they contain very little oxide of iron and alumina. 


\section{DEPOSITS OF APATITE.}

Of the Canadian apatitic deposits little is known beyond the fact that they consist of pockets (or bunches) of highgrade phosphate of lime, of crystalline structure, imbedded in granite, gneiss and mica-slate. Occasionally light-green, six-sided prismatic crystals of pure apatite are found. The commercial samples consist of hard crystalline masses, of a greenish or yellowish color, contaminated somewhat with adhering fragments of the "gangue" rock. It is claimed that very considerable quantities of apatite exist in Canada; but possibly owing to their occurrence in widely separated pockets, the cost of excavation and hand-trimming from the accompanying rock and the great expense of transportation, not much of it is met with in the phosphatic trade. The production heretofore has not certainly exceeded ten thousand tons annually, and possibly not much over five thousand. It is almost entirely consumed in New England and Great Britain. Last autumn very startling reports were spread as to the discovery of a true vein of apatite in Canada, and much anxiety was entertained as to the effect on the price of South Carolina rock, but since then no corroboration has followed.

Canadian apatite is difficult to grind, and in spite of its very high content (eighty per cent.) of phosphate of lime, its conversion into super-phosphates is attended with difficulty.

\section{Norvecgian Apatite.}

A few years since a vein of apatite was discovered at Odegaarden, not far from Langesund, on the Southern coast of Norway, which has since then been worked by the Bamble Phosphate Company and others on a considerable scale. It was found in the face of a low rocky ledge, occurring in mica and a clay-slate. Its length is about five hundred yards; its thickness one to four feet. Much difficulty is experienced from the occurrence of "horses," i. e. masses of the "gangue" rock in the vein, and the spring- 
ing of water: and the expense of preparing the rock for market by hand-trimming is great. The present annual production barely reaches a few thousand tons. The extent of the deposit was estimated at seventy-five thousand tons. The first quality of apatite contains cighty-five to ninety per cent. bone phosphate of lime, selling for thirty dollars perton; the point of shipment is some three and onehalf miles distant, whither it is transported in small mountain wagons.

\section{CONCLUDING REMARKS.}

You will observe appended to the analysis of the various foreign phosphates, on the table to which your attention has been called from time to time this evening, some comparative results obtained on the rock from different localities in this State.

If we confine our attention cxclusively to the grade of the super-phosphates manufactured from this suite of samples cxamined in this laboratory, you will note the following averages:

Super-Phosphates Manufactured.

Frome

Contain of Soluble Phosphoric alid.

P'er Cent.

Cambridge Coprolites................ Io

French Coprolites................. $71 / 2$

Bordeaux Phosphate.............. 5 to 15

German Phosphate................. \& to io

Spanish l'hosphatc................ g to 20

Navassa Phosphate................ II $1 / 2$

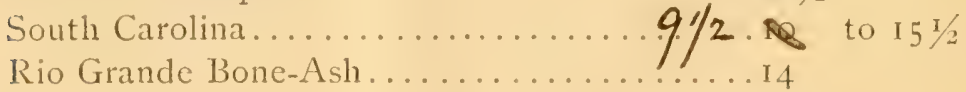

While I have not hesitated to employ this criterion as the basis of our rather practical survey this evening, it would be certainly amiss to ignore another mode of com- 
parison which possesses a like interest and profit. You are aware that considerable use is made of phosphate rock simply ground to a fine powder, and applied to the soil by itself, or in conjunction with potash salts, burnt marl, stable manure or other fertilizing materials. Without cntering upon a discussion of the merits of this procedure, I would call your attention to the following table, which gives the average results of a long series of examinations as to the solubility of the different ground phosphates in a solvent which is supposed to approximate in its effect to the action of the waters occurring in soils.

Amonnt of Phosphoric Acid dissolated on treatment of the fincly ground Phosphates from the following localitics, with an uniform quantity of ncutral-citrate-of-ammonia solution, (spec. grav. I.09) :

Per Cent.

Cambridge Coprolites................... 0.85

French Coprolites................... 0.6.5 to 1.77

Bordeaux Phosphate..................35

German P'hosphate.................. 2.00 to 2.40

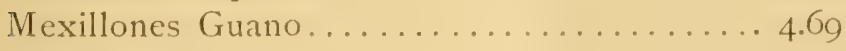

Raza Island...................... I5.83

Rio Grande Bone-Ash .............. 4.95

South Carolina Phosphatc Rock........... 2.2 I to 6.30

While it must be admitted that this method of investigation, as to the comparative assimilability of the various phosphates, leaves much to be desired, yet there is a considerable valuc to be attached to the results, conducted as they were in an uniform manner. Attention is called to the fact that the South Carolina phosphates are, on the average, as readily attacked as the Mexillones guano, and the Rio Grande bone-ash, and much more so than the French and German phosphates, which have been used for a long timeand, as is claimed by some, successfully-in the simple pulverized condition as a means of supplying the requisite phosphatic pabulum to plants. 
The lateness of the hour precludes anything more than a brici summary of the commercial situation. Assuming that of the two hundred thousand tons of phospliate rock now raised from the various South Carolina mines, one-third is consumed at home, and two-thirds are exported, chiefly to England, we see at once how seriously the price of our commodity must be affected by any new -or increased competition in the English market.

At this moment the stagnation and anxiety in commercial opcrations on the other side of the Atlantic, have unquestionably depressed the price of phosphates in general. It is to be expected that a reaction must come some time, and that the demand will once more become active. When that day shall, happily, have arrived, will there be room for a yet larger consumption of South Carolina rock? My remarks this evening have been designed to put you in a position to answer this important question.

The old beds-on which the English market relied-have either failed entirely, or show evidence of carly exhaustion, with the exception of the Spanish, more especially that of Logrosan, which looms up like a spectre.* Is there any probability of the discovery of a new deposit? In answer to this question, it must be remarked that the great varicty of occurrence, form and color, which mark phosphatic substances, are favorable to their having been overlooked or neglected even in regions where considerable attention has been bestowed on the development of mineral wealth.

For the sake of the State, of the community, of us all who are here assembled, it is to be hoped that with an increasing demand for phosphates, no other bed may be discovered or give unexpected increase of yield, so that we may reap a long and rich harvest from our Bonanza.

Trusting that you have derived information which may prove of value to yourselves, from this evening's occupation, and thanking you for your courteous attention, I close.

\footnotetext{
*In recalling the various materials which have been presented to your consideration, you will please note that bones which now go very generally to the sugar refiner, come ultimately into agricultural use after having served in the clarification of syrups.
} 
COMMERCIAL PHOSPHATES,

ACCORDING TO ANALYSES EXECUTED IN THE LABORATORY OF

DR. SHEPARD, CHARLESTON, S. C.

Whence the samples were obtained.

Those marked with an asterisk were collected by Dr. Shepard on the spot.

Those in italics are commercial samples.

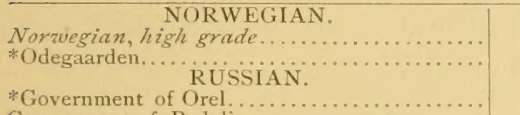

\section{Governineit of Poidi...}

ENGLISH.

* Cambridgeshire Coprolites. Cambridgeshire Coprolites.
FRENCH.

Grand Pré, Ardennes.

Varennes, Meuse.

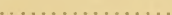

Ardennes Coprolites.

* Bellegarde Coprolites.

* Bordeaux (Lot), high grade.

*Bordeaux (Lot), low grade.

Bordeaux (Lot), Tarne-et-Garoune

Bordeaux Phosphate.

Bordeaux Phosphate.

\section{GERMAN}

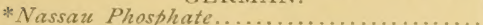

Nassau, inferior.

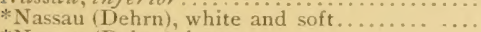

* Nassau (Dehrn), brown

* Nassau (Dehrn), yellowish brown .............

* Nassau (Dehrn), black. ............................

Hörde, black phosphatic slate................ SPANISH.

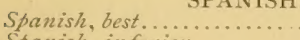

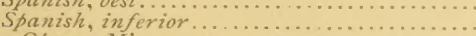

Cáceres Mines-

*Abundancia

*Estrella, white and hard.

* Estrella, rosy and pulverulent...

(n.........

* San Eugenio.

Rosa, at Malpartida...........................

Logrosan Mines-

*Yellowish-white and hard.

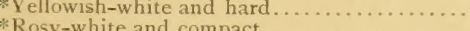

*White, soft and mammillary.

*White and hard.

Zarza la Mayor.

WEST INDIAN

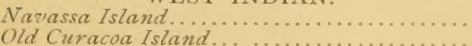

New Curacoa Island.

Sombrero Island . . . . . . . . . . . . . . . . . . . . .

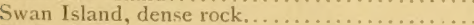

Redonda Island.

Elroque Island .

\section{PACIFIC OCEAN}

Raza Island.

Mexillones

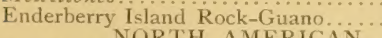

Rio Grande Bone-Ash.

Canadian A patite.

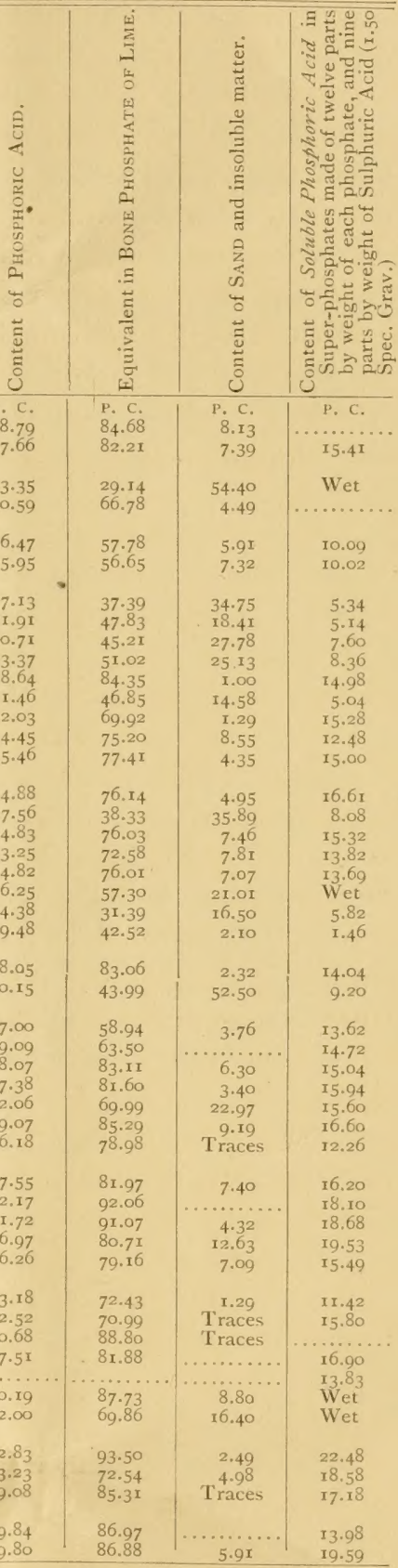

The Samples marked "Wet" failed to dry sufficiently to allow of their chemical examination. 


\section{SOUTH CAROLINA PHOSPHATES.}

Super-phosphates, made according to the foregoing proportions from the under-mentioned localities:

\section{Local.ities.}

Yielded of Soluble Phosphoric Acid-P. C.

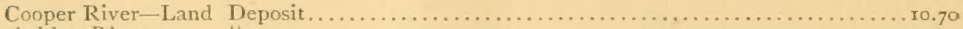

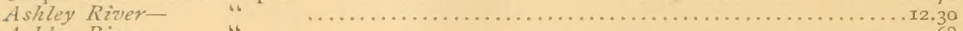

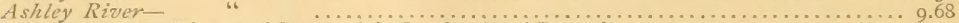
Between Ashley River and Rantowle's Creek-Land Deposit ...................

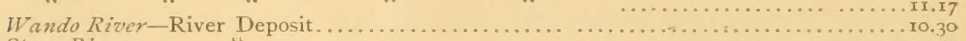

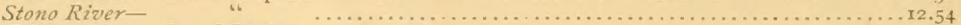

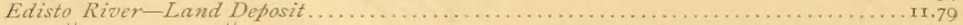

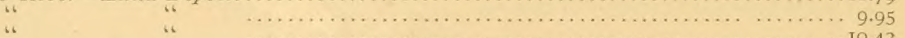

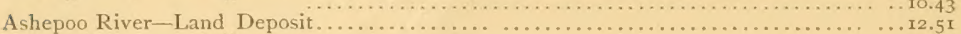

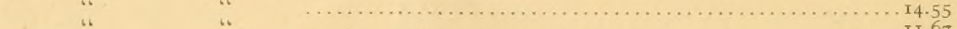

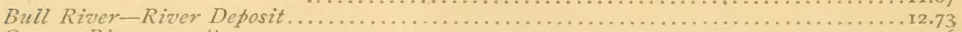

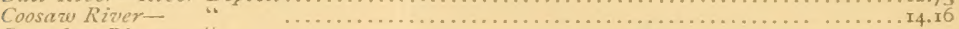

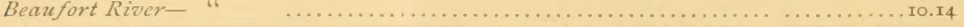

E R R A T A.

Page 6-9th line from bottom read " acid" for "acids."

" 7-6th line from top read "speedy" for "spedy."

" Io-I4th line from bottom insert "frecal" before word "accumulation."

" I6 - 5th line from top read "exuvire" for "exuvial."

" 18 -bottom line read " Rhone" for "Rhine."

" $30-5$ th line from bottom read " $9 \frac{1}{2}$ " for " 10 ," 

